\title{
EXPLORATION OF EURASIAN PRISON CHAPLAINS' PSYCHOLOGICAL WELL-BEING TO RAISE THEIR JOB SATISFACTION
}

\author{
Jan Ignatsson \\ GNJ\&PM International, Sweden \\ Indra Odina \\ University of Latvia, Latvia
}

\begin{abstract}
The article aims to attract the attention of policymakers, educators, businessaffiliated bodies, and community to the psychological well-being of such prison staff members as chaplains whose job satisfaction will directly influence inmates' rehabilitation and the health of the society in general. A phenomenological research was carried out in a non-profit organization Good News Jail and Prison Ministry whose mission is to provide spiritually mature, equipped, and motivated chaplains serving in 22 states, one American territory and 25 countries. The research sample was the participants of six Eurasian regions. The data were collected using interviews, diary notes and reports of stakeholder and problem tree analysis. The literature review and the gained data reveal a clear profile of what and who prison chaplains should be to guide prisoners towards their integration into society. It exposes both sides of the same system, known as penitentiary, as well as indicates problem solution strategies as well as requirements to maintain the work in line with trends in the branch. The research has brought repeatedly proved evidence that the complicity of "state of the art" calls for more attention from policymakers, educators, business-affiliated bodies, and states clearly that more research is necessary.
\end{abstract}

Keywords: job satisfaction, prison chaplains, psychological well-being.

\section{Introduction}

The fact that there is a strong correlation between chaplain's proficiency and inmates' rehabilitation has been studied for a significant period of time, supported in literature, analysed through a number of documents gained with different data collection methods, and confirmed in this research as well. While there are a number of other factors and people which affect inmates' life and thinking, there is no such an important profile within the whole prison staff as a chaplain whose professional qualifications and personal qualities make such a unique combination known as someone's psychological well-being.

The aim of the research was to study the psychological well-being of prison chaplains and explore their job satisfaction as well as ability to influence inmates' 
rehabilitation in the context of organizational change through educational efforts. A phenomenological research was chosen to study six participants (chaplains) in Eurasian regions: Latvia, Lithuania, Russia/ Krasnoyarsk, Russia/ Tyumen, Ukraine, and Kyrgyzstan. The following data collection methods: interviews, diary notes, and reports of stakeholder and problem tree analysis were applied.

The literature review outlined a clear portrait of a prison chaplain, traditionally presented and studied in a number of European countries as well USA, whose both professional duties and personal ambitions are committed to prisoners' integration into society, exposed both sides of the same system, known as penitentiary as well as indicated problem solution strategies as well as requirements to maintain the work quality in line with trends in the branch. The research focused on a non-profit organization Eurasian Good News Jail and Prison Ministry (GN) prison chaplains and repeatedly proved evidence that the complicity of "state of the art" called for more attention from policymakers, educators, community and stated clearly that follow-up research was needed.

\section{Research Review on Chaplains’ Psychological Well-being Aspects}

Since prison chaplaincy appeared it has been followed, influenced, and studied by society around. Despite the research done on prison chaplaincy as such, the psychological well-being of chaplains that could further influence prisoner rehabilitation is a little-researched phenomenon. The review of the research performed on the issues of chaplaincy has been carried out based on the so-called six-factor model of psychological well-being, introduced by C. Ryff which focuses on self-acceptance, personal growth, purpose in life, positive relations, autonomy, environmental mastery (Ryff, 1995).

The indicators of self-acceptance are the state of being proud of oneself and perceiving one's good and bad personality aspects and life events in a positive way. Personal growth is characterized by the person's openness to new experience, the realization of one's potential and improvement of behaviour during lifetime. Concerning the purpose in life, the respondents might express determination, clear understanding of one's goal in life, a sense of direction and confidence in life. Positive relations with others will be evident as interest in and concern to maintain positive relationships with others, even in the cases of contradictory opinions. The ability to affect the world around and competence to effectively manage and use the environment, the flow of information is characteristic to environmental mastery. Finally, autonomy is revealed in human judgments and independence, in the ability to resist public pressure and the ability to regulate their own behaviour, as well as the ability to think and act in the selected direction (Mikelsone \& Odina, 2016). 
Self-acceptance. While L. Lloyd-Rees (1971, p. 9) in D. Scott (2013) provides a clear and definitive statement on what a prison chaplain is about, describing him as a "prophet, priest and pastor" (Scott, 2013, p. 49), challenged to fit into secular culture with its strife "for excellency and accountability" according A. Aldridge (2006), "open and flexible... spiritual drivers and enablers" (Paterson, 2015, p. 4), people with their calling for life E. Pumpura (2017), A. Todd reveals the greatest antagonism and tragedy and shows the opposite side of chaplaincy with its non-prison, independent and neutral status, not seen as a "part of either prison management or the regime” (Todd, 2013, p. 146). “The chaplain's contribution to the history of the prison is probably one of the most important yet underrated of all the members of the prison staff (Scott, 2013, p. 27). Those 'dogooders', which officers and governors often want to suppress” (Scott, 1996, p. 53), "naive idiots" (Scott, 1996, p. 64) under the dominant pressure of the penal system and indifference from society describe themselves as having a poor selfimage (Smith, 1997).

S. Reimer (2010) in his research on the well-being of Canadian pastors reminds that job satisfaction being a pastor relates to age, stress level, areas of weakness, and congregation. The younger pastor is, the more stress the job duties cause, the more time is spent in areas of weakness, the higher tensions between the pastor and the congregation are the less job satisfaction (and as result wellbeing) it will bring. Similar connections are seen in another research on demographic characteristics of prison chaplains which states that chaplains are usually male (85.2\%), white (84.2\%), Master (62.2\%), Bachelor (13.4\%), and Doctoral degree (16.5\%) holders, trained in pastoral counselling $(70.3 \%)$, protestant (69.4\%) in their religious affiliation with mean age of 56.5 years and mean age experience of 10.3 years.

Thus, the research of literature has discerned several features which distinctly indicate that those working in branch 1 . definitely have high selfacceptance which allows them to go through this high opposition of penal routines, stand for their beliefs in spite of all the resistance around; 2. are welleducated, self-sufficient, self-guided, and even self-critical, which logically leads to the next conclusion; 3. are too critical for themselves that it even causes poor self-image; 4. yet are dependent on such demographic factors as age, gender, and race, the factors which serve as a solid ground and premise for a successful ministry to those incarcerated and build foundation for common sense of wellbeing.

Personal growth. In those countries where the penitentiary has been known for centuries, prison chaplaincy introduces the whole idea of felony-penaltyfavour. Prison chaplaincy concept refers to 220 years historical records which declare that the glorious profile of a prison chaplain is still "under reconstruction" (Ignatssons, 2020, p. 101), and provide through ages documented testimony that 
prison chaplaincy then and now is challenged to develop constantly and full heartedly. The dynamics of prison chaplaincy development in general causes every chaplain to change in reaction to new requirements expected from his personality. The fact that the society is no longer "strongly underpinned primarily to Christian values" (Smith, 1997, p. 49), and chaplains are "increasingly threatened with a large number of Buddhists, Muslims and Hindus" (Scott, 1996, p. 51), where welfare "specialists" put the end to "compulsory attendance at chapel" (Scott, 2013, p. 27), and the attempts to reconcile high ranked German SS officers with global society and get them to "admit their crimes before humanity" (Kellenbach, 2004, p. 34) totally fail, it requires "new legitimacy of and need for chaplaincy" including it "on multidisciplinary teams", with further "exploration of the potential role of faith based initiatives" (Timmins et al., 2018, p. 18) which basically means that there is a need for "a new wave of growth" (Ignatssons, 2020, p. 22).

Thus, as it is seen above the chaplains tend to have grown up to a solid age, significant understanding, and yet to be supportive to the inmates' new life and new start in their life (Sundt, Cullen, 2002, p. 65). The same point of view brings S. Reimer (2010) when explaining that younger pastors are more critical of their congregations, while aging pastors "become less idealistic or more competent as they age" (Reimer, 2010, p. 11).

Purpose in life. Prison chaplains certainly differ from all other prison staff as much as "theology of punishment" deviates from the "theology of rehabilitation" (Ignatssons, 2020, p. 36). These are two opposite and distinguished behaviours with two very different purposes. S. Reimer (2010) outlines a similar problem in his research on pastoral well-being when a pastor has one purpose while the congregation has quite a different vision and is not able to agree on common agenda, satisfying both parties; it is exactly when "pastoral job satisfaction suffers" (Reimer, 2010, p. 13). Prison chaplains (in 86\% cases), compared to other groups of society, strongly believe in the inmates' ability (and legal right) to rehabilitate during their imprisonment and thereafter (Sundt, Cullen, 2002, p. 66). Thus, the professional goals and personal beliefs of a prison chaplain meet and form their life credo. This group of clergy has their unique convictions.

Positive relations. The well-being of a prison chaplain in the context of their positive relations can be described as "on the fence in between" as stated by D.Scott (1996, p. 50 referring to Stokes (1988, p. 3)). Due to the reason that prison chaplains are exposed to dehumanization and "brutal behaviour of their fellow officers" (Sundt, Dammer, \& Cullen, 2002, p. 372) require the other relationships to be as positive as possible in order to balance their well-being and raise job satisfaction. The recipients of chaplain services are most likely to be those "good guys" who somehow influence chaplain's job satisfaction and appreciate their 
efforts and through-battle carried support. However, a number of researchers might oppose such an assumption and note that prisoners are "lads off the streets", "who rarely rehabilitate" (Scott, 1996, p. 15), who know and have experienced what dehumanisation can be like (Ignatssons, 2020, p. 38), coming from homes with improper duties of parents, and usually low neighbourhoods, as stated by H. Smith (1997 referring to Forsythe (1987)). Those prisoners, whom chaplains would count with were mentioned as "many who claimed to be converts", but "were not", those, who were either "hypocrites", or "weak willed victims of temptation", or who used to become penitents - "who wept and prayed out of nervous depression" (Scott, 1996, p. 36). So, if the chaplain receives much satisfaction neither from prison staff/ system, nor from the inmates themselves where does it come from? S. Reimer (2010) also indicates that there "are the positive correlations between job satisfaction and relational support, such as having help in areas of weakness and having a confidant” (Reimer, 2010, p. 8).

This is also true vice versa - having neither a confidant, nor any relational support where they would need it can bring to an opposite effect. Another positive correlation was found when examining congregation's health and pastor's wellbeing, where "the tendency of the congregation to burn out pastors" was obvious in relation to "the financial well-being of the congregation" (Reimer, 2010, p. 8).

So, these all above mentioned statements show how fragile the status of positive relations for every chaplain is. He has not got much support for rehabilitation work in the eyes of either inmates or prison staff. However, according to J. L. Sundt, H. R. Dammer and F. T. Cullen (2002) in this great conflict of the society, especially in how they conceptualized penitentiary punishment systems there was another group - "members of the public who believed in religious forgiveness” (Sundt, Dammer, Cullen, 2002, p. 373).

Autonomy. Chaplains' real autonomy rests from one side on their perception of their freedom and independence in their work duties and on the other side on the freedom and independence they provide for their beneficiaries. In the context of well-being a number of researchers shed light on autonomy pointing out the holistic model of ministry where the "whole person and his well-being" (Ignatssons, 2020, p. 48) was studied and not only "focused on clinical benefits" (Timmins et al., 2018), but also executed positive power, was able to give, support, nurture people, be responsible for others. "It is about partnership and cooperation...; it is about influencing the process of individual and cultural transformation within the penal system" (Smith, 1997, p. 252).

As it is seen above the real autonomy prevails only there where the others' autonomy is preserved, defended, and cultivated. L. Griscenko (Griščenko, 2016) provides another prerequisite that catalyses the autonomy processes in the healthcare sector and "focuses on the patient's quality of life maintenance and improvement", where three parties (chaplain, hospital staff and patient) 
collaborate. The idea that the high level of autonomy can be reached only alongside other humans/ with other groups, specialists and their determined efforts, or/ and in interaction with them was also supported by S. Reimer who found that pastors, especially young ones, would benefit (become more independent) from administrative help, others would need a confidant, mentorship in special cases, and, as prerequisite number one - the leadership/ taskmasters "should have reasonable workload expectations from their pastors" (Reimer, 2010, p. 12).

Environmental mastery. Prison chaplains being "on the fence in between" (Stokes (1988, p. 3) in Scott (1996, p. 50)) demonstrate a great skill of mastering the two worlds, a skill to find a balance as well as advocate for inmates in such a way that criminals feel guilty and willing to repent. They are being "mocked and teased in a large group of inmates, however, never denied the right to be there and serve "the therapy of sharing a trouble" (Scott, 1996, p. 68) still remain to be "the objects of fun and attacks of ridiculous secular doctrines" (Ignatssons, 2020, p. 34 ), and yet they deeply believe and perfectly demonstrate what "unconditional love, mercy, compassion and forgiveness" (Ignatssons, 2020, p. 34) are about. Only so "can he maintain his independent witness and exercise a ministry of reconciliation" (Scott, 1996, p. 50).

Managing work duties, ministerial functions, as well as executing their civil rights, prison chaplains face all sorts of challenges and needs during their life journey which influence job satisfaction and well-being. L. Yang (2018) studies well-being and even measures it to find that "income receives the lowest relative weight" for many groups of population and shows that "many studies comparing people within countries have found only a small effect of income on life satisfaction relative to other life circumstances" (Yang, 2018, p. 15). "Health, on the other hand, receives a very high weight” resumes L. Yang (2018, p. 16). In accordance with the latest findings of S. Reimer (2010) and L. Yang (2018), it is clear that prison chaplaincy sustainably develops and flourishes when the following requirements are met: 1 . there is a necessary administrative help; 2 . there is an access to a confidant; 3. mentorship is available; 4 . the level of stress due to workload is manageable, not overloaded. Studies point out that prison chaplaincy is required to demonstrate sharpened professional competence and sets a high moral standard for their personal qualities.

\section{Methodology}

The phenomenological research method was used to carry out research, the data were collected by interviews, participants' diaries and the analysis of the Stakeholder and Problem Tree reports. The focus was on deliberate experience or "lived experience" research. The phenomenological research contained four 
stages: bracketing, intuiting, analysing the data and describing the data (Langdridge, 2007) (see Table 1).

This phenomenological research was a part of a larger scale of "Contextual and Collaborative Action Research with Interactive/ Collaborative inquiry features where participants - co-researchers were invited to design their "future" (further development)" (Ignatssons, Odina, 2020, p. 113). It united both the academic intentions (presented by the University of Latvia) to study the phenomenon and the organizational known as GNJ\&PM International (abbreviation for Good News Jail and Prison Ministry).

It is a non-profit organization whose mission is, to provide spiritually mature, equipped, and motivated Christian chaplains. GNJ\&PM International is the largest independent supplier of chaplains for jails and prisons worldwide, serving in 22 states, one American territory and 25 countries. It attempts to qualitatively transform as well as develop globally the cooperation with the partner countries and foster the development of harmonious and prosperous economic and political links between old and new states in order to bring a change into existing organizations or even to start new ones.

Table 1 Phenomenological Research Process

\begin{tabular}{|c|c|}
\hline Research stage & Specification \\
\hline $\begin{array}{l}\text { Bracketing } \\
\text { stage }\end{array}$ & $\begin{array}{l}\text { Research problem outline: respondents who had undergone the identical } \\
\text { phase; limited staff (more than } 83000 \text { inmates for only } 42 \text { chaplains); } \\
\text { enormous workloads (Every prison facility is apr. } 1000-2000 \text { inmates } \\
\text { (in.), where Latvia app. } 500 \text { in./chaplain (ch.), and chaplain available } 40 \\
\text { hours/week; Russia, Ukraine, Kyrgyzstan ap. } 1300-1500 \text { in./ch., frequency } \\
\text { - } 2 \text { hours/week); political, social, religious, economic unfavourable } \\
\text { conditions (Russia, Kyrgyzstan, Ukraine, partly Lithuania, least Latvia). } \\
\text { Leaders of national prison ministries, known as GNJ\&PM (GN) National } \\
\text { Directors (NDs) } 6 \text { (only NDs) up to } 12 \text { people (ND and his deputy) }\end{array}$ \\
\hline Intuiting stage & $\begin{array}{l}\text { The researchers learnt about the phenomenon as described by the } \\
\text { participants. During this stage the target sample was identified and the data } \\
\text { were collected locally (the interaction chaplain-inmate in their } \\
\text { geographical regions) and online (between chaplains (NDs) and the } \\
\text { researchers - via ZOOM, WhatsApp, GOOGLE Classroom; Participants } \\
\text { collaborate online mainly) } \\
\text { Stratified random sampling (6 NDs - presenting sample all Eurasian GN } \\
\text { PC (totally 43) was used. } \\
\text { The interviews were semi-structured, the participants were asked to answer } \\
20 \text { questions with possible additional questions, if necessary. The data were } \\
\text { collected in the respondents' mother tongue: Latvian, English or Russian. } \\
\text { Interviews lasted from one to four hours. }\end{array}$ \\
\hline
\end{tabular}




\begin{tabular}{|l|l|}
\hline Analysing & $\begin{array}{l}\text { Research question: what Eurasian prison chaplain's well-being is and } \\
\text { how their job satisfaction could be raised. }\end{array}$ \\
\hline $\begin{array}{l}\text { stage } \\
\text { stage }\end{array}$ & $\begin{array}{l}\text { The data were categorized according to 6 positive psychological well-being } \\
\text { factors: self-acceptance, positive relations, environmental mastery, } \\
\text { personal growth, autonomy, purpose in life. In total six interview } \\
\text { transcripts, 63 diary entries and six analysis of Stakeholder and Problem } \\
\text { Tree reports were approached to seek what meaning and structures emerge. }\end{array}$ \\
\hline $\begin{array}{l}\text { The interpretation of the consolidated data. Initially, at this stage, all the } \\
\text { structural descriptions associated with every individual were synthesized } \\
\text { to determine the psychological meaning and furthermore to describe } \\
\text { invariable characteristics across the description. The focus of the study was } \\
\text { on seeing these aspects holistically - in the centre there was a prison } \\
\text { chaplain with his unique experience that was based on the lived } \\
\text { experiences of well-being. Well-being was examined to reveal a deeper } \\
\text { understanding of this concept, collect unique data, and the result of the } \\
\text { phenomenological research would possibly encourage other individuals to } \\
\text { realize their well-being potential, as well as future studies in this field. }\end{array}$ \\
\hline
\end{tabular}

\section{Research Results}

The results are grouped in three major categories and form a sufficiently full picture of Eurasian prison chaplains' well-being in general, their professional needs and personal motivation as well as problems they face in their field of their ministry in the context of their job satisfaction in particular.

Analysis of the interview on Eurasian chaplains' well-being significantly indicated the following distinctive features 1 . a various family background, with quite a similar state formation (all coming from the former Soviet Union); 2. a dramatic change respondents experienced in their life (five out of six cases); 3. being not interested in sports, training programmes, neither willing to mention any diseases or illnesses; 4 . not being able to reason about their salaries (especially respondents in the eastern countries); 5 . having a real danger while performing their ministerial or work duties (three respondents); 6. having different hardships at service performance (five respondents).

To compare Eurasian GN prison chaplains' status of well-being to that, found in literature review the following contradictory facts should be mentioned.

Self-acceptance. Four respondents have got a positive marital life experience, two - have experienced negative consequences of poor family life and "insufficient parental care", all the respondents like what they do, however, sometimes (in three cases) their relatives do not share the respondents' "new religious experiences" neither their "new services", but in three cases respondents have a strong supportive backup from their own families. In two cases the 
respondents have experienced divorce and discouraging effects of it. Current marital status is outlined by four respondents as positive experience. Two respondents have experienced the negative touch of prison life, criminality, and drug dependence a rather long time ago. They are very careful to "not traumatize people and in opposite they love people and working with people". Concerning respondents' transformation experience, five respondents have experienced a dramatic change in their professional career that can also add an extra value to their self-acceptance status. They also enjoy their personality and, as it is traditionally accepted by most evangelicals, they still work on their behaviour and habits. Through all the interviews there was a thread of satisfaction in every respondent's response on what they did and how they felt about what they did. So, the question if the respondents are satisfied with their life is absolutely "Yes". Thus, they can do a lot more for others.

Personal growth. Despite health limitations and past unhealthy lifestyle (three respondents), the desire to develop both professionally and personally was strongly expressed by all respondents. Respondents' answers revealed the specific interest for their ministerial duties and quite limited attention to political, social, cultural life/ organizations that the respondents would be members of. The people who are satisfied with their job situation, however, want a constant development in their professional duties and are considered as good and potential co-workers.

Purpose in life. According to the respondents' answers there are clear indicators that there is a purpose in life in each case. The respondents demonstrated their awareness of what sort of purpose they were inspired through their commitment to Christian values, readiness to act the way they were treated themselves. They believed: 1. "God loved them" and 2. "God loved the other people" which would give them a special motivation to behave accordingly and show no indications of "existential pains and endless theories of fruitless philosophies". However, there would be difficulties in trying to measure their unwillingness (or willingness) to be "only one profession representative... and work at one place only". Cultural differences are obvious here because some of the cultures treat chaplaincy as "a highly appreciated title rather than a routine job within prison system". Some answers showed the respondents' unwillingness to discuss their loyalty to current GNJ\&PM organization due to so many new things that they had experienced during the last 6 months. "Changing work, employer, working habits are considered to be a bad style and poor personal life management in Swedish culture", however, the societies the respondents come from do not resist any work, employment, or working habit changes.

Positive relations. Empathy, caring, supporting others' relationships were traced through the interview "I love to be with people... I cannot be alone. I need to be with others and do something. I love ministering to people. To see people change. It makes me warm" and showed the respondents' concern object - 
inmates "when somebody repents, changes, transforms, somebody's got a new life, car, house, family", prison staff and even church members. As mentioned above the family backup was referred to as a substantial resource of energy and positive emotions of prison ministers.

Autonomy. The respondents showed their concerns about what the interviewer meant with "autonomy" and indicated the variety of different interpretations so common to cross-cultural networks. The interview responses raised a number of topics for further discussion which can be channelled to several Eastern-Western contradictions: "being rich meaning independent" in the East requires another virtue - "being in collaboration/ in the right relationship with others means being independent" in the West. "Being tightly related to their congregations" caused a sense of freedom in the East while "a reasonable distance from other groups" was cherished in the West. The respondents from Western countries showed independence by being open and transparent, honest and in harmony with their inner self, while Eastern respondents put more value to independence related to being closed, hiding or even suppressing their real self, being in accordance with the politically correct concepts rather than their personal beliefs and motives.

Environmental mastery. The respondents as Christian chaplains demonstrated the ability to "affect the world around". They were acquainted with dependencies, experienced their own (in three cases) negative criminal backgrounds, struggled with absence of mentorship, yet managed "to stay clean". According to communication psychology the respondents' leadership styles could be classified as analytical thinker in two cases, supporter in two cases, real director in one case and initiative leader in one case. Concerning research respondents, these styles of leadership were more limited (in four cases) in their ways to manage or even exploit the environment. Despite they inhabited very different leadership styles and were critically limited to perform their ministerial duties, the respondents mastered the uprising situations very efficiently.

The analysis of dairies and Stakeholder and Problem Tree reports gave an understanding of what sort of job satisfaction experienced Eurasian prison chaplains. National directors' dairies and report analysis pointed out the current state of the art of Eurasian prison chaplaincy in detail, which exposed by occupation in five cases, not being loyal (or attentive) to the vision of the organization (five cases), disappointed or discouraged with expectations from GN leadership on how chaplains would perform their duties in all cases. During the thorough report analysis the following facts were identified: 1 . there had been many other groups of people connected to the ministry than those 80 thousand inmates in 80 facilities, reaching up to 1.200 .000 people in total; 2 . some of those groups needed immediate and urgent attention even more acute than the inmates; 3. several simultaneous processes were identified in organizational development 
dynamics during the research pointing out deficits in organizational structure, communication and staff interaction.

Stakeholder and Problem Tree analysis brought the final clarity of what chaplains' professional expectations and personal interests would be in the context of sustainable development and what sort of problems should be dealt with in order to conquer the hostile opposition from the outsiders and refurnish unfavourable working conditions.

Stakeholder Tree introduced two major interested parties, their interests, the requirements for their continuous support of the ministry, and appropriate participation mechanism. Both National Directors and chaplains: 1.urgently needed training of new skills, "improved job prospects", better work practice as well as motivating work environment; 2 . required (in order to stick to organization/ vision) administrative, pastoral care, strong partnership, access to training, participation in international projects; 3. would participate in updates on ministry progress, in training design, in local ministry vision/ goal identification.

Problem Tree analysis exposed four crisis areas such as material and technical base, legal status, prison administration, partnerships (Christian and other NGOs). While the "tree's" roots began deep in economic and political instability (all but Latvia), accompanied with "intolerance from the society towards protestant Christians (evangelicals)" the branches of the "tree" would expose the current stage of GN prison chaplains in Eurasia: 1. who had no work equipment, no office inside nor outside of prison, "chased after money", or struggled to "find time for ministry"; having all those deficits stuck in the situation where there was no work process, which meant zero production outcomes; 2. being "persona non grata", they faced identification problems, being not accepted by government nor welcomed by society; 3 . watching the society rejecting inmates and "negating prisoners' rights to the second chance life" caused a situation where not only job satisfaction but also well-being of prison chaplains in Eurasia was endangered.

\section{Conclusions and Discussion}

The findings of the research in combination with literature review pointed out to two quite different simultaneously existing profiles of a prison chaplain the first one belonging to old European countries (most referred in the academic literature to) with long pastoral tradition while the other ones coming from former Soviet Union countries (the participants of this research) with quite a short history record. While the traditional chaplain is highly educated, with mean age of 56,5 years and 10 years of experience in the field, self-sufficient, self-guided, and, possibly, because of that self-critical of his colleague from Eurasian GN prison chaplaincy who is much younger (mean age 42,6), much lower educated (no 
bachelor, master, doctor degree holders were found during the research), having experienced a dramatic change in their life, yet self-accepted, supported by their families, possibly more optimistically tuned.

The common for both groups remain their love and caring for people, and belief in the moral right for the second chance. Both groups indicated their willingness to grow personally and professionally, while the traditional chaplains, influenced by the dynamics in the whole penitentiary system just followed the stream in order to remain in the prison system structure, their Eurasian GN colleagues tried to find and establish their place within developing correctional institutions in the newly announced democratic countries. Both groups possess a unique feature, known as calling of God - call for their life, strong convictions, well-formulated life credo which promotes their and other people's well-being, includes inmates' rehabilitation and, thus, fully rests on the forgiveness of sins the bill is paid - no worries about it anymore.

The only difference which slightly discerns the groups is: the first ones have not had criminal background while the representatives of the other group have been in the role of inmate in 30\% of cases. Their positive relations have roots in fellowship with people having the same moral platform to such an extent that it is possible to generate enormous encouragement and inspiration in struggle with the punitive systems, hostile societies, asocial norms, and behaviours.

Autonomy was perceived and exposed by each group in quite a different way. While Eurasian GN prison chaplains understood their independence status in the light of higher social status, obtaining more power, stronger influence on others, and even prevailing over average economical level, the traditional chaplains considered their independence only in context of other people being around, in rather tight collaboration/ interaction with others, with effective models of cooperation when there was no need to suppress, prevail, dominate. Western prison chaplaincy in the sense of job satisfaction in short and well-being in long term relies upon administrative support, mentorship, access to a confidant, controlled work stress level and thus demonstrates highly professional competence and service, not laying too much focus on income, while their Eastern followers not having an appropriate income face daily difficulties and hinder with not less engagement and proficiency than those on the West.

The research deepened the understanding of the real state of Eurasian GN prison chaplains. Thus, in the light of the sustainable development of the prison chaplaincy, the foundational factors required for organizational growth and staff motivation were identified. Due to the collected data on the crucial dissatisfaction with the current status of prison chaplain (which contradicted with the interview on well-being) it was found that chaplains' personal life (and psychological wellbeing) had no connection with their job satisfaction to such an extent as of those in the West. The Stakeholder Tree analysis clearly declared what sort of state the 
chaplains would fight for, live to, long after and stressed out that without paying attention to their professional needs and personal interests the organizational move forward would not be possible. Problems that chaplains faced testified that those people, their local organizations were pioneers and first explorers in those dark places, yet still just at the starting point of the ministry initiation (an absolute exception was Latvia, where chaplaincy was established by the state; Lithuania, though, was partly accepting GN chaplains who had to struggle for their religious neutrality themselves).

The research analysis has raised rather more questions for the researchers than produced ready recipes. Before the research started in their initial ambition the researchers had planned to design an educational platform for professional chaplain training to maintain their well-being (Ignatssons, Odina, 2020). However, during the research and afterwards, the findings lead to other conclusions. Thus, in the light of organizational change the educational focus should be drawn to the implementation of any measures which would favour Eurasian GN prison chaplains' loyal connection to the global network and vision concept, promoting their personal interests, and professional competence growth. Now the motives of the Eurasian chaplains to grow professionally/ personally are likely to be caused by the desire for superiority and excellence.

Another discovery alongside the research showed that national directors were not so enthusiastic about any organizational change as the researchers had thought before which affected the process later to a substantial extent. It could point out to the situation when the workloads exceeded the workforce capacity.

Chaplains' perception of autonomy, naive and modest anticipations while dealing with such strongholds as dictatorial and reactive government establishments and still mastering their service performance in the middle of the battle show how much should be done in order to build a common ground of values for both Eastern and Western chaplaincy profiles in order to win humanity.

The final question generated by this research left the researchers without any profound explanation and totally disabled the programme for prison chaplain professional education. Which direction should the chaplain choose: from prison towards society or from society towards prison? GNJ\&PM has invested 20 years of faithful support and parental guidance, laid foundation for the ministry to inmates, repeatedly shown the direction - towards prisons, towards inmates, from outside inside and thus, has succeeded. However, today the great shift has taken place in cultures, sciences, businesses, even in the ministerial field - from solo to orchestra - from one to many, from inside towards outside. Shall the chaplain stay alone in his job satisfaction and well-being or share it with many others, is the question. 


\section{References}

Aldridge, A. (2006). The Unique Role of a Chaplain. Scottish Journal of Healthcare Chaplaincy, Vol 9 (1). DOI: 10.1558/hscc.v9i1.18

Griščenko, L. (2016). Kapelāna loma pacientu aprūpē un sadarbība ar māsām. Mağistra darbs. Rīga: Latvijas Universitāte.

Ignatssons, J. I. (2020). Pastāvošā stāvokḷa analīze Eirāzijas cietuma kapelānu profesionālo vajadzību noteikšanai. Maǵistra darbs. Rīga: Latvijas Universitāte.

Ignatssons, J. I., Odina, I. (2020). State of the Art Analysis and Professional Needs Identification in Vocational Training Design for Eurasian Prison Chaplains. In Human, Technologies and Quality of Education: Proceedings of Scientific Papers Rīga: Univeristy of Latvia, 109-121. DOI 10.22364/htqe.2020.

Kellenbach, K. (2004). God's Love and Women's Love: Prison Chaplains Counsel Wives of Nazi Perpetrators. Journal of Feminist Studies in Religion. 20(2), 7-24. DOI: 10.2979/FSR.2004.20.2.7

Langdridge, D. (2007). Phenomenological Psychology Theory, Research, and Method. England: Pearson Education Limited.

Mikelsone, I., Odina, I. (2016). Male Teachers' Well-Being in the Context of Professional Identity. In ICLEL 2016: 2nd International Conference on Lifelong Education and Leadership for All, Conference Proceeding Book, Turkey, Sakarya University Faculty of Education, 19-27.

Paterson, M. (2015). When the Chaplain is Ready the Teacher will Appear. Health and Social Care Chaplaincy, Vol 3, No 1. DOI: 10.1558/hscc.v3i1.27524

Pumpura, E. (2017). Kolārkrekla kā garīdznieka amata tērpa lietošanas izpratne luterāṇu, katoḷu un baptistu tradīcijā Latvijā. Bakalaura darbs. Rīga: Latvijas Universitāte.

Reimer, S. (2010). Pastoral Well-being: Findings from the Canadian Evangelical Churches Study. Church and Faith Trends. The Centre for Research on Canadian Evangelicalism. August 2010/ Volume 3/ Issue 2.

Ryff, C. (1995). Psychological Well-Being in Adult Life. Current Directions in Psychological Science, Vol. 4, No. 4, 99 - 103.

Scott, D. (1996). Heavenly Confinement? The Role and Perception of the Prison Chaplain in England. Lambert Academic Press.

Scott, D. (2013). Priests, Prophets and Pastors: The Historical Role of the Prison Chaplain. Justice Reflections, Vol. 31.

Smith, H. (1997). Chaplaincy, Power and Prophecy in the Scottish Prison System: The Changing Role of the Prison Chaplain. Doctoral Thesis. Edinburgh: The University of Edinburgh.

Sundt, J.L., Cullen, F.T. (2002). The Correctional Ideology of Prison Chaplains: A National Survey. Journal of Criminal Justice, 30, 369-385.

Sundt, J.L., Dammer, H.R., Cullen, F.T. (2002). The Role of the Prison Chaplain in Rehabilitation. Journal of Offender Rehabilitation, Volume 35, Issue 3-4, 59-86.

Timmins, F., Caldeira, S., Murphy, M., Pujol, N., Sheaf, G., Weathers, E., Whelan, J., Flanagan, B. (2018). The Role of the Healthcare Chaplain: A Literature Review. Journal of Health Care Chaplaincy, 24(3), 87-106. DOI: 10.1080/08854726.2017.1338048.

Todd, A. (2013). Preventing the "Neutral” Chaplain? Practical Theology, 6 (2), 144-158. DOI: 10.1179/1756073X13Z.0000000006 
SOCIETY. INTEGRATION. EDUCATION

Proceedings of the International Scientific Conference. Volume IV, May $28^{\text {th }}-29^{\text {th }}$, 2021. 342-356

Yang, L. (2018). Measuring Well-being: A Multidimensional Index Integrating Subjective Well-being and Preferences. Journal of Human Development and Capabilities, 19(4), Informa UK Limited, trading as Taylor \& Francis Group, 456-476, DOI: 10.1080/19452829.2018.1474859 